\title{
Improvement in Growth Parameters, Yield Attributes and Economics of Groundnut (Arachis hypogaea L.) through Graded Levels of Hydrogel Application
}

\author{
M. S. Vivek ${ }^{1}$, Parashuram Chandravanshi*, S. P. Nataraju², \\ Sarvajna Salimath ${ }^{1}$ and A. H. Kumar Naik ${ }^{3}$
}

${ }^{1}$ Department of Soil Science and Agricultural Chemistry, College of Agriculture, Shivamogga, University of Agricultural and Horticultural Sciences, Shivamogga-577201, Karnataka, India

${ }^{2}$ Department of Crop Physiology, University of Agricultural and Horticultural Sciences, Shivamogga-577201, Karnataka, India

${ }^{3}$ Zonal Agricultural and Horticultural Research Station, Babbur Farm, Hiriyur, University of Agricultural and Horticultural Sciences, Shivamogga-577201, Karnataka, India

*Corresponding author

Keywords

Hydrogel, groundnut, Growth parameters, Yield attributes

Article Info

Accepted:

26 March 2020

Available Online:

10 April 2020

\section{A B S T R A C T}

A field experiment was conducted during Kharif 2018 at Zonal Agricultural and Horticultural Research Station, Hiriyur, University of Agricultural and Horticultural Sciences, Shivamoggato study the effect of various levels of hydrogel, farm yard manure (FYM) and mulching on growth parameters, yield attributes and economics of groundnut cultivation under the rainfed condition. Results revealed that, treatment with the application of recommended dose of fertilizers (RDF) along with hydrogel @ $4 \mathrm{~kg} \mathrm{ha}^{-1}$ and FYM @ $10 \mathrm{t} \mathrm{ha}^{-1}$ was recorded significantly higher plant height (6.45, 17.83 and $30.14 \mathrm{~cm}$ ) and number of branches (4.91, 7.52 and 9.27) at 30, 60 and 90 DAS, respectively and also yield attributes viz., number of pods per plant (25), pod yield per plant (4.57 g), shelling percentage $(67.41 \%)$, dry pod yield $\left(1470 \mathrm{~kg} \mathrm{ha}^{-1}\right)$, kernel yield $\left(991 \mathrm{~kg} \mathrm{ha}^{-1}\right)$ and haulm yield $\left(3114 \mathrm{~kg} \mathrm{ha}^{-1}\right)$ at harvest with higher gross returns (Rs.62, $560 \mathrm{ha}^{-1}$ ), net returns (Rs.25, $760 \mathrm{ha}^{-1}$ ) and benefit-cost (B: C) ratio (1.70). Significantly lower growth and yield attributes were noticed in treatment with no hydrogel and manure application. 


\section{Introduction}

Groundnut (Arachis hypogaea L.) is an essential edible oil and food crop of the world. It is an annual and highly selfpollinated crop belongs to the family leguminaceae and subfamily Papilionaceae. Groundnut is native to Brazil and it is grown mainly in the tropical and sub-tropical regions of the world. It was introduced to India during the $18^{\text {th }}$ century. It is a unique crop with attributes of both oil and proteins, consisting of 44 to 50 per cent of edible oil and 25 per cent of high-quality protein. Since groundnut is an energy-rich crop and it needs fertile and well-aerated soils. In recent years, it has been shown that the area under groundnut in dry lands is decreasing gradually, due to erratic rainfall and low moisture availability at critical stages. Under these circumstances, we have to raise a crop by utilizing less amount of water and should produce maximum yields in turn. So, the combined use of hydrogel and nutrient management appears to be the best alternative to get higher pod yields with enhanced seed quality.

In arid and semiarid regions with limited soilwater availability, hydrogel polymers are the materials for enhancing water and nutrient use efficiency. When the root zone of the plant dries up, the hydrogel is able to retain water, plant nutrients and release it to the plant. Nowadays soil moisture conservation is considered one of the significant challenges for countries in arid and semi-arid regions. By 2030, global water demand is probable to be 50 per cent higher than today, resulting in water scarcity, at the same time the agricultural sector uses over 70 percent of freshwater in most regions of the world.

A hydrogel is a biodegradable superabsorbent polymer which can hold 400 to $500 \mathrm{~g}$ of water per gram of dry hydrogel. It has greater potential in storing water available for plant growth and production. Hydrogel, when used properly in an ideal situation, 95 per cent of its stored water willbe available for plant absorption (Nazarli et al., 2010).

Indian Agricultural Research Institute (IARI), New Delhi has developed the hydrogel, which are cross-linked polyacrylamide polymers (PMA). These are semi-synthetic superabsorbent and biodegradable polymers which absorb water and release it to the soil when moisture drops. They are made up of water-insoluble acrylate and potassium acrylamide. The hydrogel was a long parallel chain of molecules and when cross-linked, they can form a network of polymeric chains. Water is brought into the network by process of osmosis and quickly moves into the plant system and it is reserved. When the hydrogel absorbs water, it appears as a gel, amazingly hydrogel can absorb up to 300 to 500 times more water than its weight and when surroundings begin to dry out, the hydrogel gradually dispenses up to 95 per cent of their stored water. When they are exposed to water again, they will rehydrate and repeat the process of storing water. This process can last up to several years when the biodegradable hydrogels decompose. The hydrogel attaches itself to the roots and sheds water under water deficit conditions and nourishes the crop. Due to its sticky nature, hydrogel binds to fertilizers and reduces fertilizer leaching. The polymeric hydrogel is a boon for the dryland ecosystems subjected to various moisture stresses.

\section{Materials and Methods}

A field experiment was conducted during Kharif 2018 at the Zonal Agricultural and Horticultural Research Station, Babbur farm, Hiriyur, Karnataka. The experiment consisted of ten treatments and three replications, treatments involving hydrogel (Fig. 2) application with four doses of the hydrogel, 
i.e., 1.0, 2.0, 3.0, $4.0 \mathrm{~kg} \mathrm{ha}^{-1}$ and FYM 10 $\mathrm{t} \mathrm{ha}^{-1}$, mulching with pongamia green leaf at $4.0 \mathrm{t} \mathrm{ha}^{-1}$. RCBD design was used in a test crop groundnut (G-2-52 variety) with spacing $30 \mathrm{~cm} \times 10 \mathrm{~cm}$. During the investigation, various biochemical properties of groundnut were analysed at different growth stages.

\section{Experimental details}

Experimental Design : Randomized complete block design (RCBD)

$\begin{array}{lll}\text { No. of Treatments } & : & \text { Ten } \\ \text { No. of Replications } & : & \text { Three } \\ \text { Test crop } & : & \text { Groundnut } \\ \text { Variety } & : & \text { G2-52 } \\ \text { Spacing } & : & 30 \mathrm{~cm} \times 10 \mathrm{~cm} \\ \text { Gross plot size } & : & 5 \mathrm{~m} \times 4.5 \mathrm{~m} \\ \text { Season } & : & \text { Kharif } 2018 \\ \text { Date of sowing } & : & 14-07-2018 \\ \text { Date of harvesting } & : & 03-12-2018\end{array}$

\section{Treatment details}

$\mathrm{T}_{1}: \mathrm{RDF}$ (Control)

$\mathrm{T}_{2}: \mathrm{RDF}+1.0 \mathrm{~kg}$ hydrogel ha ${ }^{-1}$

$\mathrm{T}_{3}: \mathrm{RDF}+2.0 \mathrm{~kg}$ hydrogel ha ${ }^{-1}$

$\mathrm{T}_{4}: \mathrm{RDF}+3.0 \mathrm{~kg}$ hydrogel ha $\mathrm{h}^{-1}$

$\mathrm{T}_{5}: \mathrm{RDF}+4.0 \mathrm{~kg}$ hydrogel ha ${ }^{-1}$

$\mathrm{T}_{6}: \mathrm{T}_{2}+10$ tons of FYM ha ${ }^{-1}$

$\mathrm{T}_{7}: \mathrm{T}_{3}+10$ tons of FYM ha ${ }^{-1}$

$\mathrm{T}_{8}: \mathrm{T}_{4}+10$ tons of FYM ha ${ }^{-1}$

$\mathrm{T}_{9}: \mathrm{T}_{5}+10$ tons of FYM ha ${ }^{-1}$

$\mathrm{T}_{10}$ : RDF + Mulching

RDF: Recommended dose of Fertilizers-50 per cent $\mathrm{N}+100$ per cent $\mathrm{P}$ and $\mathrm{K}$ as basal dose and 25 per cent $\mathrm{N}$ each at 25 and 40 DAS.

$\mathrm{RDF}=25: 50: 25 \mathrm{kgN}: \mathrm{P}_{2} \mathrm{O}_{5}: \mathrm{K}_{2} \mathrm{Oha}^{-1}$ (Rainfed)

\section{Growth parameters}

The plant height was recorded at 30,60, 90 DAS and at harvest from the surface of the soil to the tip of plant of the five randomly selected plants in all the treatments. The average plant height was computed and expressed in centimetre.

The total number of branches per plant was counted at 30, 60, 90 DAS and at harvest from five labelled plants in the respective treatment.

\section{Yield and yield attributing parameters}

After separating and drying the pods from randomly selected five plants, the number of pods per plant was recorded and weight of pods per plant was recorded and expressed in grams. The pod yield per hectare was calculated using pod yield per plot.

Harvest index was calculated by using the formula.

Harvest index $(\mathrm{HI})=\frac{\text { Economic yield }}{\text { Biological yield }}$

The known weight of dried pods from each treatment was shelled manually and the weight of the kernel was recorded. The shelling percentage was calculated as follows:

Shelling $(\%)=\frac{\text { Weight of kernels obtained }(\mathrm{g})}{\text { Weight of pods used for shelling }(\mathrm{g})} \times 100$

Hundred seeds were counted manually from a sample drawn from each treatment in four replications and weighed as per the procedure given by ISTA (2012). The kernel yield and haulm yield per hectare were calculated using kernel yield and haulm yield per plot, respectively.

\section{Economics}

The cost of cultivation per hectare was calculated for the individual treatment based on inputs used and the prevailing market price of the produce. Gross monetary returns were 
estimated by multiplying economic yield with the current market price of groundnut pods.Net returns (Rs. ha ${ }^{-1}$ ) were calculated by deducting the cost of cultivation from gross monetary returns for each treatment. Benefitcost $(\mathrm{B}: \mathrm{C})$ ratio was calculated by dividing gross returns with the cost of cultivation.

Benefit: cost (ratio) $=\frac{\text { Gross returns }\left(R s \cdot h a^{-1}\right)}{\text { Cost of cultivation }\left(R s \cdot h a^{-1}\right)}$

\section{Statistical analysis}

The experimental data obtained were subjected to statistical analysis by adopting Fisher's method of analysis of variance as outlined by Gomez and Gomez (1984). The level of significance used in the ' $F$ ' test was at 5 per cent.

\section{Results and Discussion}

\section{Growth parameters}

The plant height fairly gives the idea of photosynthetic capacity due to the application of hydrogel combined with RDF and FYM. The increase in plant height (Table 1) was mainly due to the good moisture and nutrient supply along with fair weather condition at critical growth stages. As the water content of the plant increases, it leads to the increased cell swelling and turgor pressure against cell walls.

Therefore, application of RDF, hydrogel and FYM increase the turgor pressure inside the cells by maintaining sufficient amount of water as per plant need and thus causing an increase in plant height. Similar results were also reported by Al-Harbi et al., (1999).

The treatment $\left(\mathrm{T}_{1}\right)$ with the application of only recommended dose of NPK was recorded lower plant height. This is because of early response of the treatment to water deficit condition. As the water content of the plant decreases, there will be cell shrinkage and turgor pressure against cell walls will be relaxed. This lowered cell volume resulting from the lower turgor pressure subsequently accumulates solutes in cells (Otitoloju, 2014).

Number of branches per plant was the indication of overall utilization of resources and better light interception. It increased significantly with the application of RDF, hydrogel @ $4 \mathrm{~kg} \mathrm{ha}^{-1}$ along with FYM application@10 $\mathrm{tha}^{-1}$. Increased number of branches per plant (Table 1) was due to the higher synthesis in carbohydrates, proteins, total amino acids and other biochemical and physiological parameters, especially in the presence of hydrogel polymer with the supply of sufficient moisture for plant growth during the moisture stress conditions.

Similarly, a significant increase in the number of branches and other growth parameters were due to the application of hydrogel polymer with RDF and FYM application was reported by Silberbush et al., (1993) in peanut, Akhter et al., (2004) in barley and wheat. Increased concentration of hydrogel showed increased number of branches per plant and also resulted in more retention of moisture and indirectly the availability of nutrients. It might help to increase the activity of cell division, expansion, elongation and ultimately leading to the increased number of branches per plant.

\section{Yield attributes}

Treatment $\left(\mathrm{T}_{9}\right)$ with the application of recommended dose of NPK along with hydrogel $\left(4.0 \mathrm{~kg} \mathrm{ha}^{-1}\right)$ and FYM (10 $\left.\mathrm{t} \mathrm{ha}^{-1}\right)$ differed significantly in yield attributes viz., number of pods and pod yield per plant, test weight, shelling percentage, pod yield, kernel yield and haulm yield (Sahana, 2016) (Table 2 and Fig. 1). 
Table.1 Effect of hydrogel application on growth parameters in groundnut at different growth stages

\begin{tabular}{|c|c|c|c|c|c|c|c|c|}
\hline \multirow[t]{2}{*}{ Treatments } & \multicolumn{4}{|c|}{ Plant height $(\mathrm{cm})$} & \multicolumn{4}{|c|}{ No. of branches per plant } \\
\hline & 30 DAS & 60 DAS & 90 DAS & At harvest & 30 DAS & 60 DAS & 90 DAS & At harvest \\
\hline$T_{1}: \operatorname{RDF}($ Control $)$ & 4.27 & 15.43 & 26.12 & 34.15 & 3.12 & 5.45 & 7.36 & 8.45 \\
\hline$T_{2}:$ RDF+ $1.0 \mathrm{~kg}$ hydrogel ha ${ }^{-1}$ & 4.58 & 15.68 & 26.54 & 34.67 & 3.19 & 5.56 & 7.45 & 8.61 \\
\hline$T_{3}:$ RDF +2.0 kg hydrogel ha ${ }^{-1}$ & 4.91 & 16.01 & 27.41 & 35.08 & 3.47 & 5.72 & 7.68 & 8.94 \\
\hline $\mathrm{T}_{4}: \mathrm{RDF}+3.0 \mathrm{~kg}$ hydrogel ha- ${ }^{-1}$ & 5.13 & 16.31 & 27.61 & 35.72 & 3.85 & 5.91 & 7.89 & 9.15 \\
\hline $\mathrm{T}_{5}: \mathrm{RDF}+4.0 \mathrm{~kg}$ hydrogel ha ${ }^{-1}$ & 5.20 & 16.57 & 27.95 & 36.12 & 3.99 & 6.14 & 8.21 & 9.35 \\
\hline$T_{6}: T_{2}+10$ tons of FYM ha ${ }^{-1}$ & 6.05 & 17.08 & 28.14 & 37.54 & 4.21 & 6.54 & 8.46 & 9.81 \\
\hline$T_{7}: T_{3}+10$ tons of FYM ha ${ }^{-1}$ & 6.14 & 17.24 & 28.67 & 37.91 & 4.39 & 6.98 & 8.67 & 9.97 \\
\hline$T_{8}: T_{4}+10$ tons of FYM ha & 6.31 & 17.45 & 29.54 & 38.48 & 4.62 & 7.35 & 9.03 & 10.24 \\
\hline$T_{9}: T_{5}+10$ tons of FYM ha ${ }^{-1}$ & 6.45 & 17.83 & 30.14 & 38.74 & 4.91 & 7.52 & 9.27 & 10.51 \\
\hline$T_{10}:$ RDF+ Mulching & 5.28 & 16.31 & 27.99 & 36.51 & 4.02 & 6.18 & 8.29 & 9.17 \\
\hline S. Em ( \pm$)$ & 0.20 & 0.23 & 0.58 & 0.73 & 0.22 & 0.38 & 0.33 & 0.24 \\
\hline C.D. at $5 \%$ & 0.59 & 0.67 & 1.71 & 2.18 & 0.61 & 1.12 & 1.00 & 0.69 \\
\hline
\end{tabular}

Note: RDF: Recommended dose of fertilizers DAS: Days after sowing

FYM: Farm yard manure 
Table.2 Effect of hydrogel application on yield and yield attributes of groundnut

\begin{tabular}{|c|c|c|c|c|c|c|c|c|}
\hline Treatments & $\begin{array}{l}\text { Number of pod } \\
\text { plant }^{-1}\end{array}$ & $\begin{array}{l}\text { Pod yield } \\
\text { plant }^{-1}(\mathrm{~g})\end{array}$ & $\begin{array}{l}\text { Test } \\
\text { weight }(\mathrm{g})\end{array}$ & $\begin{array}{l}\text { Harvest } \\
\text { index }\end{array}$ & $\begin{array}{l}\text { Shelling } \\
(\%)\end{array}$ & $\begin{array}{l}\text { Dry pod } \\
\text { yield } \\
\left(\mathrm{kg} \mathrm{ha}^{-1}\right)\end{array}$ & $\begin{array}{l}\text { Kernel } \\
\text { yield } \\
\left(\mathrm{kg} \mathrm{ha}^{-1}\right)\end{array}$ & $\begin{array}{l}\text { Haulm yield } \\
\left(\mathrm{kg} \mathrm{ha}^{-1}\right)\end{array}$ \\
\hline$T_{1}: \operatorname{RDF}($ Control $)$ & 18 & 3.92 & 33.51 & 0.38 & 64.28 & 671 & 431 & 1270 \\
\hline$T_{2}: R D F+1.0$ kg hydrogel ha & 19 & 4.01 & 33.92 & 0.38 & 64.61 & 762 & 492 & 1412 \\
\hline $\mathrm{T}_{3}: \mathrm{RDF}+2.0 \mathrm{~kg}$ hydrogel ha & 19 & 4.07 & 34.38 & 0.38 & 64.95 & 835 & 543 & 1548 \\
\hline $\mathrm{T}_{4}: \mathrm{RDF}+3.0 \mathrm{~kg}$ hydrogel ha ${ }^{-1}$ & 20 & 4.17 & 34.65 & 0.39 & 65.17 & 916 & 597 & 1704 \\
\hline $\mathrm{T}_{5}: \mathrm{RDF}+4.0 \mathrm{~kg}$ hydrogel ha & 21 & 4.23 & 34.81 & 0.38 & 65.38 & 976 & 638 & 1965 \\
\hline$T_{6}: T_{2}+10$ tons of FYM ha & 22 & 4.29 & 35.15 & 0.4 & 66.12 & 1232 & 815 & 2443 \\
\hline$T_{7}: T_{3}+10$ tons of FYM ha & 23 & 4.34 & 35.37 & 0.39 & 66.49 & 1306 & 868 & 2677 \\
\hline$T_{8}: T_{4}+10$ tons of FYM ha & 24 & 4.41 & 35.76 & 0.41 & 67.16 & 1373 & 922 & 2937 \\
\hline$T_{9}: T_{5}+10$ tons of FYM ha & 25 & 4.57 & 35.92 & 0.41 & 67.41 & 1470 & 991 & 3114 \\
\hline$T_{10}: R D F+$ Mulching & 21 & 4.25 & 34.84 & 0.4 & 65.42 & 820 & 537 & 1817 \\
\hline S. Em $( \pm)$ & 0.63 & 0.12 & 0.71 & 0.04 & 0.71 & 81.1 & 59.6 & 228 \\
\hline C.D. at $5 \%$ & 1.86 & 0.37 & 2.12 & NS & 1.89 & 239.1 & 178.0 & 677 \\
\hline
\end{tabular}

Note: RDF: Recommended dose of fertilizers

FYM: Farm yard manure 
Table.3 Effect of hydrogel application on gross returns, net returns and benefit-cost (B: C) ratio of groundnut

\begin{tabular}{|c|c|c|c|c|}
\hline Treatment & $\begin{array}{l}\text { Cost of cultivation } \\
\text { ( Rs. ha }{ }^{-1} \text { ) }\end{array}$ & $\begin{array}{l}\text { Gross Returns } \\
\left(\text { Rs. ha }{ }^{-1} \text { ) }\right.\end{array}$ & $\begin{array}{l}\text { Net Returns } \\
\left(\text { Rs. ha }{ }^{-1} \text { ) }\right.\end{array}$ & $\mathrm{B}: \mathrm{C}$ ratio \\
\hline$T_{1}: \operatorname{RDF}($ Control) & 18100 & 27150 & 9050 & 1.50 \\
\hline$T_{2}:$ RDF+ $1.0 \mathrm{~kg}$ hydrogel ha ${ }^{-1}$ & 20100 & 30954 & 10854 & 1.54 \\
\hline$T_{3}:$ RDF+ 2.0 kg hydrogel ha ${ }^{-1}$ & 22000 & 34100 & 12100 & 1.55 \\
\hline $\mathrm{T}_{4}:$ RDF+ $3.0 \mathrm{~kg}$ hydrogel ha ${ }^{-1}$ & 23900 & 37523 & 13623 & 1.57 \\
\hline$T_{5}:$ RDF+ 4.0 kg hydrogel ha ${ }^{-1}$ & 25800 & 40248 & 14448 & 1.56 \\
\hline$T_{6}: T_{2}+10$ tons of FYM ha ${ }^{-1}$ & 31100 & 51315 & 20215 & 1.65 \\
\hline$T_{7}: T_{3}+10$ tons of FYM ha ${ }^{-1}$ & 33000 & 54780 & 21780 & 1.66 \\
\hline$T_{8}: T_{4}+10$ tons of FYM ha ${ }^{-1}$ & 34900 & 58283 & 23383 & 1.67 \\
\hline$T_{9}: T_{5}+10$ tons of FYM ha ${ }^{-1}$ & 36800 & 62560 & 25760 & 1.70 \\
\hline$T_{10}:$ RDF+ Mulching & 21800 & 34008 & 12208 & 1.56 \\
\hline
\end{tabular}

Note: RDF: Recommended dose of fertilizers FYM: Farm yard manure 
Figure.1 Per cent increase in pod and haulm yield of groundnut due to application of different levels of hydrogel

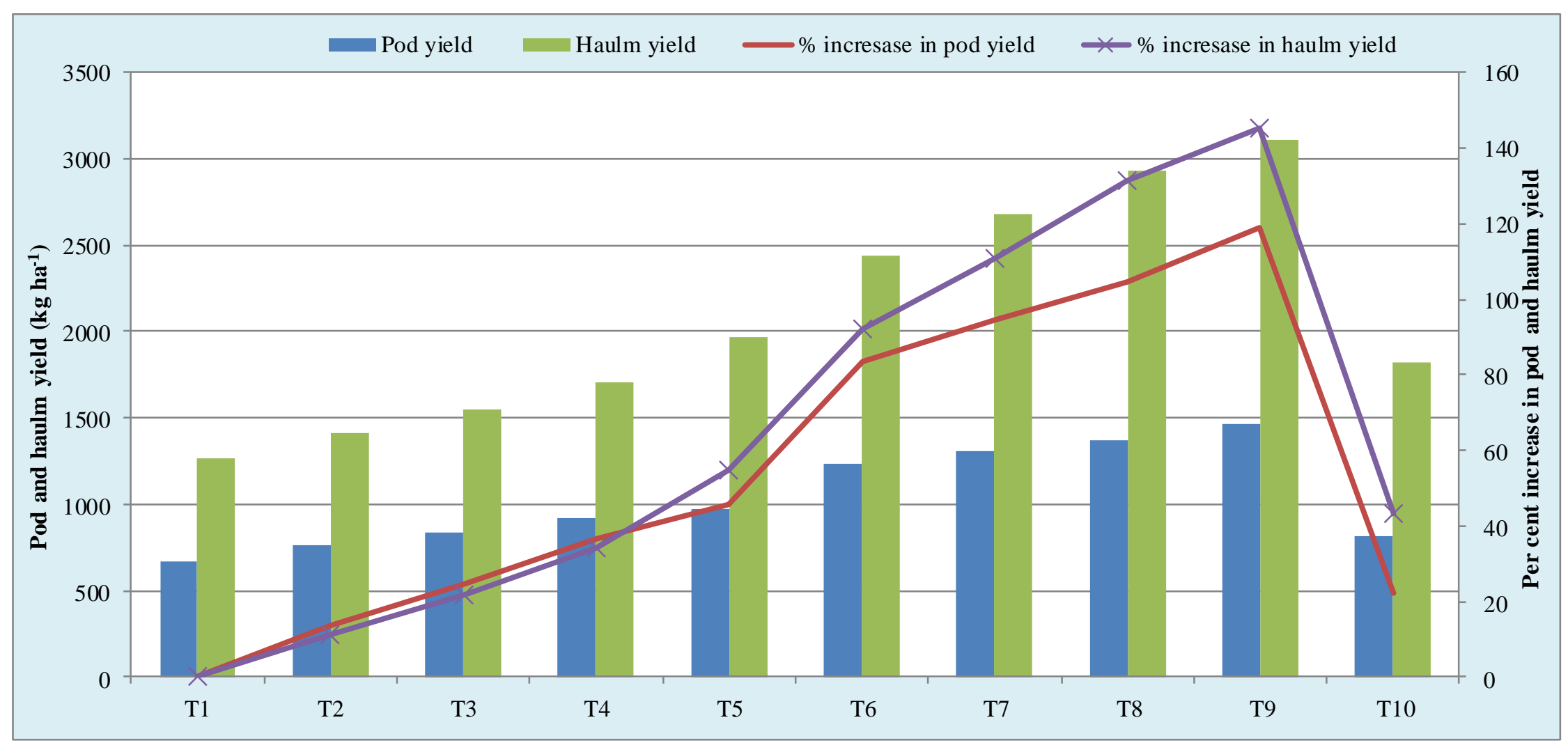

$\mathbf{T}_{\mathbf{1}}$ : Control(RDF)

$\mathbf{T}_{4}: \mathrm{RDF}+3.0 \mathrm{~kg}$ hydrogel ha ${ }^{-1}$

$\mathbf{T}_{\mathbf{7}}: \mathbf{T}_{\mathbf{3}}+10$ tons FYM ha ${ }^{-1}$

$\mathbf{T}_{\mathbf{1 0}}: \mathrm{RDF}+$ Mulching
$\mathbf{T}_{\mathbf{2}}: \mathrm{RDF}+1.0 \mathrm{~kg}$ hydrogel ha ${ }^{-1}$

$\mathbf{T}_{5}: \mathrm{RDF}+4.0 \mathrm{~kg}$ hydrogel ha ${ }^{-1}$

$\mathbf{T}_{\mathbf{8}}$ : $\mathbf{T}_{\mathbf{4}}+10$ tons FYM ha ${ }^{-1}$
$\mathbf{T}_{3}:$ RDF $+2.0 \mathrm{~kg}$ hydrogel ha ${ }^{-1}$

$\mathbf{T}_{\mathbf{6}}: \mathbf{T}_{\mathbf{2}}+10$ tons FYM ha ${ }^{-1}$

$\mathbf{T}_{\mathbf{9}}: \mathbf{T}_{\mathbf{5}}+10$ tons FYM ha ${ }^{-1}$ 
Figure.2 Hydrogel (dry)

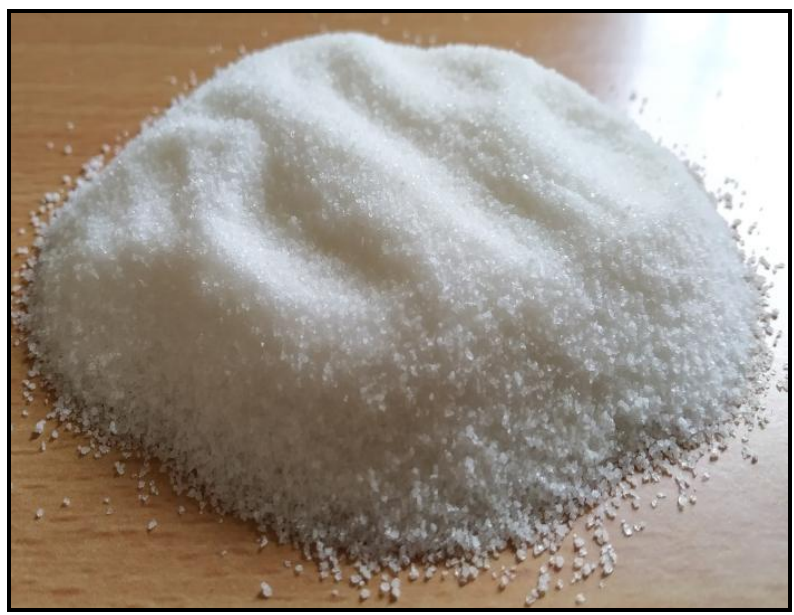

The pod yield of groundnut is influenced by dry matter accumulation in different parts, including reproductive parts. Although, the genetic composition of a crop cultivar is the primary determinant of its yield potential, the manifestation of morphological, physiological and biochemical parameters and weather parameters ultimately decide the productivity of crop in water stress condition. It mainly depends upon the production of carbohydrates, uptake of water and nutrients from the soil in addition to several environmental factors to which crop is exposed during the growing period (Sengupta et al., 2015). Application of hydrogel increases the yield and yield attributes by supplying sufficient moisture and nutrients at critical growth stages. Soil physical, chemical and microbiological properties enhance the plant growth in vegetative and reproductive phases by providing a better environment for plant growth.

Higher kernel yield was due to higher yield parameters viz., pod yield per plant, number of pods per plant and hundred pod weights. However, higher pod yield facilitates the higher number of kernels, in turn, increases the yield with higher shelling percentage. This improvement in yield components was due to the improved growth parameters such as higher plant height, chlorophyll content and number of branches per plant.

While the treatment $\left(T_{1}\right)$ which received RDF alone recorded lower yield attributes and yield compared to rest of the treatments because of insufficient soil moisture which extenuate the crop growth and ultimate reduction in yield attributes. It also might be due to without any moisture retaining materials, which in turn resulted in the reduction of photosynthetic activity and translocation of photosynthates to sink. Similar results were reported by Chaudhary et al., (2015).

\section{Economics}

The treatment $\left(T_{9}\right)$ with the application of RDF and hydrogel @ $4 \mathrm{~kg} \mathrm{ha}^{-1}$ and 10 tons FYM ha ${ }^{-1}$ recordedhigher gross returns, net returns and benefit-cost ratio (Table 3). This is mainly due to the application of hydrogel which improved the soil physical, chemical and microbiological properties. This led to the higher growth parameters and yield attributes, hence higher gross and net returns from the treatment compared to other treatments. However, the highest $\mathrm{B}: \mathrm{C}$ ratio (1.70) was 
recorded in the same treatment. The net returns and $\mathrm{B}: \mathrm{C}$ ratio was not increased much due to the combined use of the hydrogel with RDF and FYM. This was mainly due to the higher cost of hydrogel which increases the input cost or cultivation cost under rainfed condition. Hence, hydrogel usage with FYM and RDF shows a high impact on rainfed groundnut productivity. Similar results were obtained by Ramanjaneyalu et al., (2008).

The treatment with the application of RDF alone recorded the lower gross, net returns and benefit-cost ratio. It was mainly due to the lower physical, chemical and microbiological properties which lead to lower growth and yield due to moisture stress noticed at various grand growth stages.

\section{References}

Akther, J., Mahmood, K., Malik, K. A., Mardan, A. and Ahmed, M, M. 2004.Effects of hydrogel amendment on water storage of sandy loam and loam soils and seedling growth of barley, wheat and chickpea. Plant, Soil and Environment. 50(10): 463-469.

Al-Harbi, A. R., Al-Omran, A., Shalaby, A. A. and Choudhary, M. L. 1999. Efficacy of hydrophilic polymer declines with time in green house experiments. Horticultural Science. 34: 223-224.

Chaudhary, J. H., Ramdev, S. and Desai, L.J. 2015. Growth, yield, yield attributes and economics of summer groundnut (Arachis hypogaea L.) as influenced by integrated nutrient management. Journal of Applied and Natural Science. 7(1): 369-372.

Gomez, K. A. and Gomez, A. A. 1984. Statistical procedures for Agric. Res., $2^{\text {nd }}$ Ed. John Wiley and Sons, New
York.

Ista., 2012. International rules for seed testing. Seed Science and Technology. 13: 299-513.

Nazarli, H., Zardashti, M. R., Darvishzadeh, R. and Najafi, S. 2010. The effect of water stress and polymer on water use efficiency, yield and several morphological traits of sunflower under greenhouse condition. Notulae Scientia Biologicae. 2(1): 53-58.

Otitoloju, K. 2014.Effect of integrated use of soil conditioner with fertilizers on growth, chlorophyll content and yield of groundnut (Arachis hypogaea L.). Molecular Soil Biology. 5(7): 1-9.

Ramanjaneyulu, A. V., Madhavi, A., Anuradha, G., VenkataRamana, M., Suresh, G., Balaji, N., B. and Seshu, G. 2018.Agronomic and Economic Evaluation of Hydrogel Application in Rainfed Castor Grown on Alfisols. International Journal of Current Microbiology and Applied Science. 7(7): 3206-3217.

Sahana, C. S. 2016.Influence of mulching, hydrogel and nutrient management on growth, seed yield and quality of summer groundnut. M.Sc. Thesis, Univ. Agric. Sci., Bengaluru.

Sengupta, A., Gunri, S. K. and Basu, T. K. 2015.Performance of short duration groundnut (Arachis hypogaea L.) variety (TG-51) as influenced by nutrient management strategy under new alluvial zone of west Bengal. Legume Research, 39(1): 91-95.

Silberbush, M., Adar, E. and De-Malach, Y. 1993. Use of hydrophilic polymer to improve water storage and availability to crops grown in sand dunes in corn irrigated by trickling. Agricultural Water Management. 23(5): 303-313. 
How to cite this article:

Vivek, M. S., Parashuram Chandravanshi, S. P. Nataraju, Sarvajna Salimath and Kumar Naik, A. H. 2020. Improvement in Growth Parameters, Yield Attributes and Economics of Groundnut (Arachis hypogaea L.) through Graded Levels of Hydrogel Application. Int.J.Curr.Microbiol.App.Sci. 9(04): 3047-3057. doi: https://doi.org/10.20546/ijcmas.2020.904.356 